\title{
Green House Gas Mitigation Potential of Shelterbelt Trees in Northern Transitional Zone of Karnataka, India
}

\author{
Shahbaz Noori ${ }^{*}$, H. Shivanna ${ }^{2}$ and Arun K. Asthagi ${ }^{2}$ \\ ${ }^{1}$ Department of Silviculture and Agroforestry, ${ }^{2}$ Department of Forest Biology and Tree \\ Improvement College of Forestry, Sirsi, (UASD), Karnataka 581401, India \\ *Corresponding author
}

\section{A B S T R A C T}

Keywords

Shelterbelt,

Biomass, Carbon

sink, Carbon

sequestration,

Greenhouse gas.

Article Info

Accepted:

22 August 2019

Available Online:

10 September 2019
Greenhouse gases in the atmosphere, mainly carbon dioxide $\left(\mathrm{CO}_{2}\right)$ can be mitigated by the planting of trees and shrubs. Appropriate agroforestry practices in Haveri include field and farmyard shelterbelts, monoculture plantations and managed woodlots. The objective of study was to determine the amount of carbon held in ten year old shelterbelt trees of five different species in Hanumanamatti agricultural research station of Ranebennur Taluk at Haveri District. Among the five different tree species, maximum above and below ground biomass production was recorded in Acacia auriculiformis at all stages of observations followed by Azadirachta indica and Dalbergia sissoo. The maximum carbon sequestration potential was recorded in Acacia auriculiformis at initial reading, after 3 month, 6 month, 9 month and 12 month after initial reading was $65.01 \mathrm{t} / \mathrm{ha}, 70.96 \mathrm{t} / \mathrm{ha}, 78.14 \mathrm{t} / \mathrm{ha}, 84.59 \mathrm{t} / \mathrm{ha}$, and $91.15 \mathrm{t} / \mathrm{ha}$ respectively. The findings suggest that Acacia auriculiformis, Azadirachta indica and Dalbergia sissoo are suitable to varying degrees and have implications for shelterbelt elsewhere in agroclimatic zones of Karnataka. The paper will discuss the results of this particular study and the broader implications of this work.

\section{Introduction}

Carbon dioxide concentration in the earth's atmosphere has increased from $280 \mathrm{ppm}$ in pre-industrial times to $405.93 \mathrm{ppm}$ in 2015 , mainly due to human activities (Anon, 2015). A major problem being faced by human society is global warming, which is believed to be rising due to human activities such as burning of fossil fuel (coal, oil, petroleum, and natural gas) and releasing it into the atmosphere. In order to reduce carbon concentration, the concept of carbon sequestration came into picture during 1980s. Carbon sequestration is a nature balancing process of removing of the carbon from the 
atmosphere (source) by storing it in the biomass of green plants as sink (Chavan and Rasal, 2012). Global interest in carbon sequestered by agroforestry systems increased after its recognition as a greenhouse gas mitigation strategy under the Kyoto Protocol (Nair et al., 2009). Despite their biomass production and carbon sequestration potential, agroforestry practices are not explicitly accounted for in national programs in spite of its potential to increase farm production and ecosystem services. Most of the carbon stored in form of biomass by plants in agricultural systems is seasonally released back to atmosphere upon harvesting of the particular crop. When trees are incorporated into the agriculture system in form of shelterbelts, a portion of carbon can be retained and stored for much longer periods of time as the system is not easily and quickly replaced by other practices (Schoeneberger, 2009).

Shelterbelts are widely used in agroforestry across the globe today. It consists of trees and shrubs planted in long row at farmstead or agricultural field. This agroforestry system has played a key role since the beginning of $20^{\text {th }}$ century. Besides providing protection from wind, modifying microclimate and protecting crops, it aids to minimize deleterious impacts of soil erosion (Kulshreshtha et al., 2011). Shelterbelts also limit animal waste odour from farms, lower the risk of crop damage due to pesticide spray-drift, as well as minimize the risk of potential flooding on farmyards, agricultural fields and environmental plantings (Wiseman et al., 2009). Shelterbelts also serve as wildlife habitat, improve biodiversity and water quality, and capture and store atmospheric carbon as a direct result of the growth of shelterbelt trees (Kulshreshtha et al., 2011). This speaks to the potential of shelterbelts to act as carbon credit for farmers as a method of offsetting the greenhouse gas emissions associated with land use change and agricultural pursuits.
Carbon stored in trees can easily be estimated from biomass and extensive work has been done on biomass estimation in forests as part of carbon mitigation programs (Brandies et al., 2006), but there is relatively little published biomass growth, yield and carbon sequestration potential of in shelterbelts (Zhou et al., 2007). One of the challenges for estimating biomass in windbreaks and shelterbelts is the lack of standard methods and procedures because most woody biomass equations are developed from forest stands (Nair et al., 2009). The biomass equations developed for forest stands underestimate biomass in agroforestry systems (such as shelterbelt) as trees in shelterbelts are relatively open grown compared to forest trees (Zhou, 2007). These systems are different and need to be studied because less competition and nutrient availability in agroforestry systems favor plant growth and produce higher biomass.

Determining this baseline information is the first step required to answer larger questions such as how shelterbelt trees sequester carbon over time and space. We chose five most commonly planted trees as shelterbelt for sample analysis which includes Pongamia pinnata, Dalbergia sissoo, Acacia auriculiformis, Azadirachta indica and Tectona grandis due to its importance as an abundant shelterbelt species.

\section{Materials and Methods}

Established shelterbelts of 10 year old (120 months after planting) were identified in Hanumanamatti agricultural research station (14 40'778" N Latitude, 75 36' 622” E Longitude) of Ranebennur taluk at Haveri district which falls in Northern transition agroclimatic zone - 8 of Karnataka. The shelter belt was oriented in North - South direction having red sandy loam type of soil. In this region, five shelterbelt species, 
Pongamia pinnata, Dalbergia sissoo, Acacia auriculiformis, Azadirachta indica and Tectona grandis were sampled. Trees were planted in three rows with spacing of $2 \times 2$ meter. Slow growing tree species was planted on either side of the middle row like Dalbergia sissoo, Azadirachta indica and Pongamia pinnata and relatively fast growing trees species were planted in middle row like Acacia auriculiformis and Tectona grandis. Here, each tree species was considered as a treatment with five replications in each treatment and five trees were taken for observations in each replications.

The above ground biomass was estimated by non-destructive method for different plant parts. Observation for various growth parameters viz., diameter at breast height (DBH in $\mathrm{cm}$ ) was measured with caliper and total height $(\mathrm{m})$ with digital hypsometer and the form height was calculated using Spiegel Relaskop to find out tree volume using the formula given by Pressler's (1865).

$\mathrm{F}=2 \mathrm{~h} 1 / 3 \mathrm{~h}$ where $\mathrm{f}$ is form factor, $\mathrm{h} 1$ is height at which diameter is half of $\mathrm{DBH}$ and $\mathrm{h}$ is total height. Volume was calculated by Pressler's formula (1865) i.e., $\mathrm{V}=\mathrm{f} \times \mathrm{h} \times \mathrm{g}$ where, $\mathrm{V}=$ volume, $\mathrm{f}=$ form factor, $\mathrm{h}=$ total height and $\mathrm{g}$ $=$ basal area. Above ground biomass was calculated by formula as suggested by Mac Dickens (1997). Above ground biomass = Volume x Wood density.

Below ground biomass of trees was calculated by multiplying aboveground biomass of tree with the factor 0.26 (IPCC, 1995). The data obtained were subjected to statistical analysis using Randomized Block Design of experimentation as per the procedure suggested by Gomez and Gomez (1984). The total biomass was estimated to work out the amount of carbon sequestered by reducing the total biomass yield to its 50 per cent. Wherever, the effects exhibited significance at
$5 \%$ level of probability, critical difference (CD) was calculated.

\section{Results and Discussion}

Accumulation of atmospheric carbon dioxide and entrapment in tree tissues has a strong correspondence with biomass production pattern. The biomass production is the total quantity of biomass present at a particular time in an ecosystem depicting its importance in understanding ecological and economical productivity of species (Ambily et al., 2012).

The results revealed significant difference among tree species for biomass attributes at different time intervals. The result on above ground biomass was recorded significantly higher in Acacia auriculiformis followed by Azadirachta indica and Dalbergia sissoo while lowest was recorded in Pongamia pinnat at initial reading (120 months after planting), 3 month, 6 month, 9 months after initial reading i.e., $130.19 \mathrm{t} / \mathrm{ha}, 112.64 \mathrm{t} / \mathrm{ha}$, $124.64 \mathrm{t} / \mathrm{ha}, 134.03 \mathrm{t} / \mathrm{ha}$ respectively (Table 1 ) but at 12 months after initial reading Acacia auriculiformis (144.68 t/ha) showed maximum above ground biomass followed by Dalbergia sissoo and Azadirachta indica. This maximum above ground biomass is attributed to maximum volume and wood density of the tree species which in turn could be due to maximum utilization of nutrients by these species through decomposed leaf litter and other sources of nutrients such as fertilizes applied to crops.

Below ground biomass recorded significant difference in Acacia auriculiformis followed by Azadirachta indica and Dalbergia sissoo and least was recorded in Pongamia pinnata at initial reading (120 months after planting), 3 month, 6 month, 9 months after initial reading i.e., $26.83 \mathrm{t} / \mathrm{ha}, 29.29 \mathrm{t} / \mathrm{ha}, 32.25 \mathrm{t} / \mathrm{ha}$ and $34.91 \mathrm{t} / \mathrm{ha}$ respectively but at 12 months after initial reading Acacia auriculiformis (37.62 
t/ha) shows maximum below ground biomass followed by Dalbergia sissoo (27.21 t/ha) and Azadirachta indica (27.15 t/ha) which could be due to plant produce large root system and fast growing habit of the species (Table 2).

Significant variation was also observed with respect to carbon sequestration potential. at initial reading, 3 month, 6 month, 9 months after initial reading. Acacia auriculiformis proved to sequester significantly maximum carbon followed by Azadirachta indica and Dalbergia sissoo, whereas lowest sequestration was recorded in Pongamia pinnata. At 12 months after initial reading Acacia auriculiformis shows maximum carbon sequestration (91.15 ton/ha) with a total biomass production (AGB+BGB) of about $182.3 \mathrm{t} / \mathrm{ha}$ followed by Dalbergia sissoo (65.92 t/ha) and Azadirachta indica. (65.78 t/ha) which could be attributed to maximum total biomass production and growth habit recorded in tree species (Table 3). These results are in accordance with Swamy (2010), reported in different shelterbelt trees at different time interval and also in line with Reddy et al., (2014).

Established shelter belt represent a significant carbon reservoir on the agricultural landscape. However duration of carbon offset that a shelterbelt represents depend upon its lifespan and fate. If the shelterbelt was simply removed or destroyed at end of its lifespan, the carbon removed from the atmosphere would be returned to the atmosphere. If wood from the shelterbelt was used in long term products such as lumber, the duration of the offset could be lengthened. If the biomass in the shelterbelt was used as a fuel to substitute for fossil fuel in heating or electricity generation, the offset could be considered to be a permanent one. This study was set out to determine if shelterbelt tree species in northern transition zone of Karnataka could demonstrate its potential in sequestering atmospheric carbon. Among different tree species planted in shelterbelt ecosystem Acacia ariculiformis, Azadirachta indica and Dalbergia sissoo showed its superior potential over the other species in terms of biomass production and carbon sequestration.

There are millions of shelterbelt trees and shrubs planted in Karnataka and millions more around the world, but as our results indicate, they are not created equal in terms of their carbon sequestration potential. The future study should focus on how external factors such as soil fertility and changing climate patterns might have on shelterbelt trees planted across agroecological zones of Karnataka.

Table.1 Above ground biomass ( $\mathrm{t} / \mathrm{ha}$ ) of different tree species planted under shelterbelt

\begin{tabular}{|c|c|c|c|c|c|}
\hline \multicolumn{6}{|c|}{ Above ground biomass (tones/hectare) } \\
\hline Species & $\begin{array}{c}\text { Initial } \\
(120 \mathrm{MAP})\end{array}$ & $\begin{array}{c}3 \text { MAIR } \\
\text { (123 MAP) }\end{array}$ & $\begin{array}{c}6 \text { MAIR } \\
\text { (126 MAP) }\end{array}$ & $\begin{array}{c}9 \text { MAIR } \\
\text { (129 MAP) }\end{array}$ & $\begin{array}{c}12 \text { MAIR } \\
\text { (132 MAP) }\end{array}$ \\
\hline Acacia auriculiformis & 103.19 & 112.64 & 124.03 & 134.27 & 144.68 \\
\hline Azadirachta indica & 71.38 & 79.19 & 89.62 & 99.57 & 104.41 \\
\hline Tectona grandis & 46.25 & 51.77 & 65.75 & 77.52 & 88.38 \\
\hline Dalbergia sissoo & 68.40 & 72.81 & 85.23 & 98.78 & 104.64 \\
\hline Pongamia pinnata & 27.05 & 30.11 & 39.56 & 48.50 & 51.24 \\
\hline S.Em $( \pm)$ & 10.44 & 11.10 & 11.41 & 13.47 & 12.91 \\
\hline C.D.(0.05) & 22.14 & 23.53 & 24.18 & 28.55 & 27.36 \\
\hline C.V. & 26.11 & 25.32 & 22.31 & 23.22 & 20.94 \\
\hline
\end{tabular}

(MAIR- Months after initial reading, MAP- Months after planting) 
Table.2 Below ground biomass ( $\mathrm{t} / \mathrm{ha}$ ) of different tree species planted under shelterbelt

\begin{tabular}{|l|c|c|c|c|c|}
\hline \multicolumn{6}{|l}{ Below ground biomass (ton/ha) } \\
\hline Species & $\begin{array}{c}\text { Initial } \\
(\mathbf{1 2 0} \text { MAP) }\end{array}$ & $\begin{array}{c}\text { 3 MAIR } \\
(\mathbf{1 2 3} \text { MAP) }\end{array}$ & $\begin{array}{c}\text { 6 MAIR } \\
(\mathbf{1 2 6} \text { MAP) }\end{array}$ & $\begin{array}{c}\text { 9 MAIR } \\
(\mathbf{1 2 9} \text { MAP) }\end{array}$ & $\begin{array}{c}\text { 12 MAIR } \\
(\mathbf{1 3 2} \text { MAP) }\end{array}$ \\
\hline Acacia auriculiformis & 26.83 & 29.29 & 32.25 & 34.91 & 37.62 \\
\hline Azadirachta indica & 18.56 & 20.59 & 23.30 & 25.89 & 27.15 \\
\hline Tectona grandis & 12.02 & 13.46 & 17.10 & 20.16 & 22.98 \\
\hline Dalbergia sissoo & 17.78 & 18.93 & 22.16 & 25.68 & 27.21 \\
\hline Pongamia pinnata & 7.03 & 7.83 & 10.28 & 12.61 & 13.32 \\
\hline S.Em ( \pm ) & 2.715 & 2.885 & 2.966 & 3.502 & 3.355 \\
\hline C.D.(0.05) & 5.756 & 6.116 & 6.288 & 7.424 & 7.112 \\
\hline C.V. & 26.10 & 25.32 & 22.31 & 23.22 & 20.94 \\
\hline
\end{tabular}

(MAIR- Months after initial reading, MAP- Months after planting)

Table.3 Carbon sequestration of different tree species planted under shelterbelt

\begin{tabular}{|l|l|l|l|l|l|}
\hline \multicolumn{6}{|l}{ Carbon sequestration (ton/ha) } \\
\hline Species & $\begin{array}{l}\text { Initial } \\
(\mathbf{1 2 0} \text { MAP) }\end{array}$ & $\begin{array}{l}\text { 3 MAIR } \\
(\mathbf{1 2 3 M A P})\end{array}$ & $\begin{array}{l}\text { 6 MAIR } \\
(\mathbf{1 2 6} \text { MAP) }\end{array}$ & $\begin{array}{l}\text { 9 MAIR } \\
(\mathbf{1 2 9} \text { MAP) }\end{array}$ & $\begin{array}{l}\text { 12 MAIR } \\
(\mathbf{1 3 2} \text { MAP) }\end{array}$ \\
\hline Acacia auriculiformis & 65.01 & 70.96 & 78.14 & 84.59 & 91.15 \\
\hline Azadirachta indica & 44.97 & 49.89 & 56.46 & 62.73 & 65.78 \\
\hline Tectona grandis & 29.14 & 32.62 & 41.42 & 48.84 & 55.68 \\
\hline Dalbergia sissoo & 43.09 & 45.87 & 53.70 & 62.23 & 65.92 \\
\hline Pongamia pinnata & 17.04 & 18.97 & 24.92 & 30.55 & 32.58 \\
\hline S.Em $( \pm)$ & 6.58 & 6.991 & 7.187 & 8.485 & 8.13 \\
\hline C.D.(0.05) & 13.949 & 14.82 & 15.236 & 17.987 & 17.235 \\
\hline C.V. & 26.11 & 25.32 & 22.31 & 23.22 & 20.93 \\
\hline
\end{tabular}

(MAIR- Months after initial reading, MAP- Months after planting)

\section{References}

Ambily, K. K., Meenakumari, T., Jessy, M. D., Ulaganathan, A. and Nair, U. N., 2012, Carbon sequestration potential of RRII 400 series clones of Hevea brasiliensis. Rubb. Sci., 25(2): 233240.

Anonymous, 2015, National Oceanic and Atmospheric Administration report. Mouna lao, Hawaii.

Brandies, T. J., Delaney, M., Parresol, B. R. and Royer, L., 2006, Development of equations for predicting Puerto Rican subtropical dry forest biomass and volume. For. Ecol. Manage., 233: 133142.

Chavan, B. L. and Rasal, G. B., 2012, Carbon sequestration potential of young Annona reticulate and Annona squamosa from University campus of Aurangabad. Int. J. Physical and Social Sci., 2 (3):193-198.

Gomez, K. A. and Gomez, A. A.,1984, Statistical procedures for agricultural research, John wiley and sons, Inc.

IPCC, Climate change: The Science of 
Climate Change. Cambridge University Press, Cambridge, UK. 1995.

Kulshreshtha, S., Van Rees, K., Hesseln, H., Johnston, M. and Kort, J., 2011, Issues in agroforestry development on the Canadian Priaries. In: Kellimore L (ed) Handbook on Agroforestry: management practices and environmental impact. Nova Science Publishers, New York, pp 91-127.

Mac Dicken, 1997, A guide to monitoring carbon storage in Forestry and Agro forestry, Forest carbon monitoring progrmme. Winrock publications., New York. Pp: $1-87$.

Nair, P. K., Kumar, B. M., Nair, V. D., 2009, Agroforestry as a strategy for carbon sequestration. J.Plant. Nutr. Soil Sci., 172: 10-23.

Pressler, M. R., Das, Gesetz der Stammbildung Und dessen forstwirtschaftliche., Bedentung fur den waldban hochsten, reinertrags. Arnold, Leipzig, 1865, 153p.
Reddy, M.C., Priya, R. M. and Madiwalar, S. L., 2014, Carbon Sequestration Potential of Teak Plantations of Different Agro-Climatic Zones and Age-Gradations of Southern India. Curr. World Envir., 9(3):785-788.

Schoeneberger, M. M., 2009, Agroforestry: working trees for sequestering carbon on agricultural lands. Agrofor. Sys., 15: 27-37.

Swamy, K. R., 2010, Study of carbon stocking in six shelter belt tree species. M.Sc. Thesis, Uni. Agric. Sci., Dharwad (India).

Wiseman, G., Kort, J. and Walker, D., 2009, Quantification of shelterbelt characteristics using high resolution imagery. Agric. Ecosys. Environ., 131: 111-117.

Zhou, X., Brandle, J. R., Schoeneberger, M. M. and Awada, T., 2007, Developing above ground woody biomass equations for open grown, multiple stemmed tree species: shelterbeltgrown Russian-olive. Ecol. Model., 202: 311-323.

\section{How to cite this article:}

Shahbaz Noori, H. Shivanna and Arun K. Asthagi 2019. Green House Gas Mitigation Potential of Shelterbelt Trees in Northern Transitional Zone of Karnataka, India. Int.J.Curr.Microbiol.App.Sci. 8(09): 2365-2370. doi: https://doi.org/10.20546/ijcmas.2019.809.273 